\title{
Semi-Automated Synthesis of [F-18]FBAM, a Thiol Reactive Prosthetic Group, Using Continuous Flow Chemistry
}

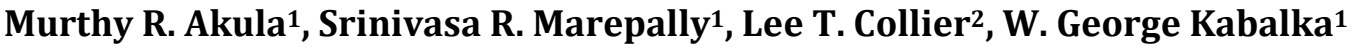 \\ ${ }^{1}$ Departments of Chemistry and Radiology, University of Tennessee, Knoxville, Tennessee, USA \\ ${ }^{2}$ Advion Biosystems, Ithaca, NY, USA \\ Email:kabalka@utk.edu
}

How to cite this paper: Akula, M.R., Marepally, S.R., Collier, L.T. and Kabalka, W.G. (2016) Semi-Automated Synthesis of [F-18]FBAM, a Thiol Reactive Prosthetic Group, Using Continuous Flow Chemistry. International Journal of Organic Chemistry, 6, 177-185.

http://dx.doi.org/10.4236/ijoc.2016.63018

Received: May 3, 2016

Accepted: September 23, 2016

Published: September 26, 2016

Copyright (c) 2016 by authors and Scientific Research Publishing Inc. This work is licensed under the Creative Commons Attribution International License (CC BY 4.0).

http://creativecommons.org/licenses/by/4.0/

\begin{abstract}
[F-18]FBAM, a thiol reactive bifunctional agent, was successfully synthesized using continuous flow chemistry in a micro reactor that is part of Advion NanoTek Microfluidic Synthesizer. As the radiofluorination was carried out microfluidically, a very small amount of precursor was used and over all radiochemical yield was $38 \% \pm 4 \%$ ( $\mathrm{n}=8$, decay corrected) and the radiochemical purity was $\geq 98 \%$ with specific activity of $430 \mathrm{mC} / \mu \mathrm{mol}$. The total reaction time including HPLC purification was $55 \mathrm{~min}$ that is 14 min more than manual synthesis and 6 min less than fully automated synthesis.
\end{abstract}

\section{Keywords}

Bifunctional Agent, Micro-Reactor, 6-Bromohexnol, Radiofluorination, Appel Reaction

\section{Introduction}

Bioactive peptides and proteins are important key regulators in cell growth and cellular functions in living organisms [1]-[3]. Various peptides, proteins, antibodies, antibody fragments and nucleotides have been radiolabeled and used to image tumors and inflammatory processes [4]. Among these tracers, [F-18] labeled molecular probes are increasingly popular because of the ease of production of ${ }^{18} \mathrm{~F}$ and its favorable properties. However, harsh reaction conditions required to directly radiofluorinate these sensitive biomolecules hampered the preparation of the requisite tracers in good yields and high specific activity. To address these problems, radiochemists have taken advantage of bifunctional agents, also known as prosthetic groups. These prosthetic groups are catego- 
rized into three classes amine, thiol and carboxylic reactive. Notable thiol reactive bifunctional agents include $\left[{ }^{18} \mathrm{~F}\right]$ FBAM [5] [6], $\left[{ }^{18} \mathrm{~F}\right] \mathrm{FBOM}[7],\left[{ }^{18} \mathrm{~F}\right] \mathrm{FBABM}$ [8], $\left[{ }^{18} \mathrm{~F}\right] \mathrm{FPyAM}[9]$ and $\left[{ }^{18} \mathrm{~F}\right] \mathrm{FPyMe}[10]$ (Figure 1).

Microfluidics represents a useful approach to conduct the reactions with minimal quantities of expensive precursors; other advantages include reduced reaction times and increased radiolabeling yields. These effects are realized due to the high surface to volume ratio encountered while the reagents are flowing through the microchannel which is accompanied by rapid mixing of the reagents leading to increased heat transfer between the reactants. One of the commercially available microfluidic devices with micro-channel system (MCS) is the Advion NanoTek Microfluidic Synthesizer. This unit consists of three modules called the reagent, reactor and concentrator modules. The isotope is dried and dissolved in the concentrator module and transferred to a loop attached to the reactor module while the precursor is stored in a second loop attached to reagent module. The reagents are then meter delivered and passed through the microreactor consisting of a $100 \mu \mathrm{m}$ channel made of quartz. We wish to report an improved synthesis of $\left[{ }^{18} \mathrm{~F}\right]$ FBAM utilizing this microfluidic system involving continuous flow.

\section{Results and Discussion}

\subsection{Chemistry}

The reported procedure for preparing requisite precursor 16 required synthesizing $\left[{ }^{18} \mathrm{~F}\right]$ FBAM via the Mitsunobu reaction of tert-butyl $N$-[(6-hydroxyhexyl)oxy] carbamate, 6 with maleimide, 8 , in the presence of $\mathrm{Ph}_{3} \mathrm{P}$, diisopropyl acetylene dicaboxylate, and DMF at $-78^{\circ} \mathrm{C}$ to obtain 7 (Scheme 1 ).

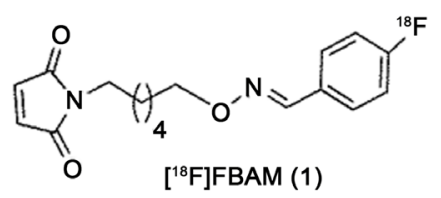<smiles>O=C1C=CC(=O)N1CCOCCN=Cc1ccc(F)cc1</smiles><smiles>O=C1C=CC(=O)N1CCCOc1cccnc1[18F]</smiles><smiles>O=C1C=CC(=O)N1CCOCCOCCON=Cc1ccc(F)cc1</smiles>
$\left[{ }^{18} \mathrm{~F}\right] \mathrm{FBOM}(4)$

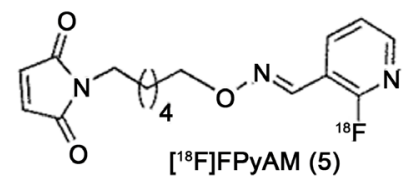

Figure 1. Notable thiol reactive bifunctional agents. 


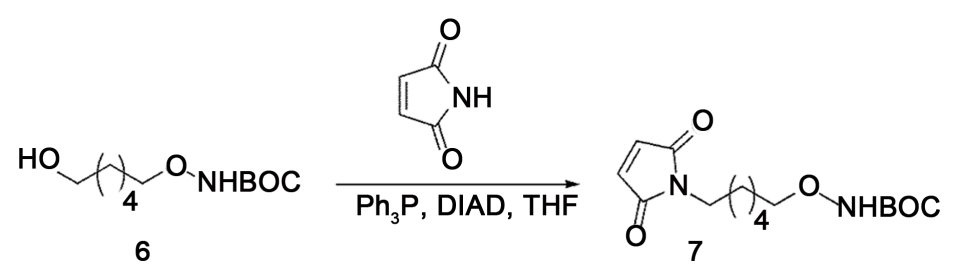

Scheme 1. Mitsunobu reaction.

Attempts to directly $\mathrm{N}$-akylate maleimide $\mathbf{8}$ with various alkyl bromides failed or produced very poor yields (Scheme 2). We then treated maleimide 8 with either $\mathrm{NaH}$ or $\mathrm{K}_{2} \mathrm{CO}_{3}$ in THF or DMF at room temperature followed by the addition of 1,6-dibromohexane, 9; after, stirring the reaction mixture at reflux only trace amounts of the desired product 11 were produced. Adding sodium iodide to catalyze the reaction did not improve the yield. Further experiments using the bromide 10 as an alkylating agent also did not result in the desired product 7. It is possible that the $N$-Alkylation of maleimide does not proceed as expected because the maleimide anion underwent a 1,4-addition to another molecule of maleimide instead of reacting with alkyl bromide.

Precursor 16 was successfully prepared from 6-bromohexanol, 12, in six steps in an overall yield of $24.6 \%$ (Scheme 3). tert-Butyl- $N$-hydroxycarbamate, 13, was then $O$-alkylated with 6-bromohexanol, 12, to obtain alcohol 6, using 1,8-diazabicyclo[5.4.0] undecene (DBU) as the base in DMF at room temperature. Appel reaction [11] of alcohol 6 to bromide 10 was achieved with carbon tetrabromide and triphenylphosphine in $\mathrm{CH}_{2} \mathrm{Cl}_{2}$ by stirring the reaction mixture at room temperature. Bromide 10 was allowed to react with sodium azide in DMF at $80^{\circ} \mathrm{C}$ to obtain azide 14 in nearly quantitative yield. The crude azide 14 was then hydrogenated with 5\% Pd-C in EtOAc to obtain amine 15 [12]. Reaction of amine 15 with $N$-methoxycarbonyl-maleimide in thepresence of $\mathrm{NaHCO}_{3}$ bin refluxing in dioxane afforded 7. The Boc-protecting group was readily removed with $\mathrm{HCl} / \mathrm{EtOAC}$ at room temperature to obtain 16 as the $\mathrm{HCl}$ salt. The condensation of $\mathbf{1 6}$ with 4-fluorobenzaldehyde in DMF at room temperature gave the 17 as a white solid.

The two step radiosynthesis of $\left[{ }^{18} \mathrm{~F}\right] \mathrm{FBAM}, 1$, was performed in the Advion NanoTek Microfludic Synthesizer (Scheme 4). Using the drying macros of NanoTek LF 1.4 software, a complex of Kryptofix $222 / \mathrm{K}_{2} \mathrm{CO}_{3} /\left[{ }^{18} \mathrm{~F}\right]$ fluoride was thoroughly dried and allowed to react with 4- N,N,N-trimethylamino-benzaldehyde triflate, 18, in a microreactor $(2 \mathrm{~m} \times 100 \mu)$ at $120^{\circ} \mathrm{C}$ to obtain $4-\left[{ }^{18} \mathrm{~F}\right]$ fluorobenz-aldehyde, 19 . The labeling efficiency under microfluidic conditions was compared with the previously reported procedures (Table 1). The outlet tube from the reactor was immersed in a reaction vial containing precursor $16(8 \mathrm{mg})$ dissolved in a 1:1 mixture of $1 \mathrm{NHCl}: \mathrm{MeOH}$ which was then heated at $75^{\circ} \mathrm{C}$ for $10 \mathrm{~min}$ to obtain $\left[{ }^{18} \mathrm{~F}\right] \mathrm{FBAM}, 1$, in higher overall radiochemical yield $(38 \% \pm 4 \%)$ when compared to the earlier reports $(29 \% \pm 4 \%)$. The crude product 1 was subjected to $\mathrm{C}_{18}$ Sep-Pak solid phase extraction before purifying on semi preparative HPLC. $\left[{ }^{18} \mathrm{~F}\right] \mathrm{FBAM}(29 \mathrm{mCi})$ was obtained from $100 \mathrm{mCi}$ of $\left[{ }^{18} \mathrm{~F}\right]$ fluoride in $55 \mathrm{~min}$, including HPLC purification, in a radiochemical purity of $\geq 98 \%$. The identity of the product was confirmed using analytical HPLC by co-elution with 17. 


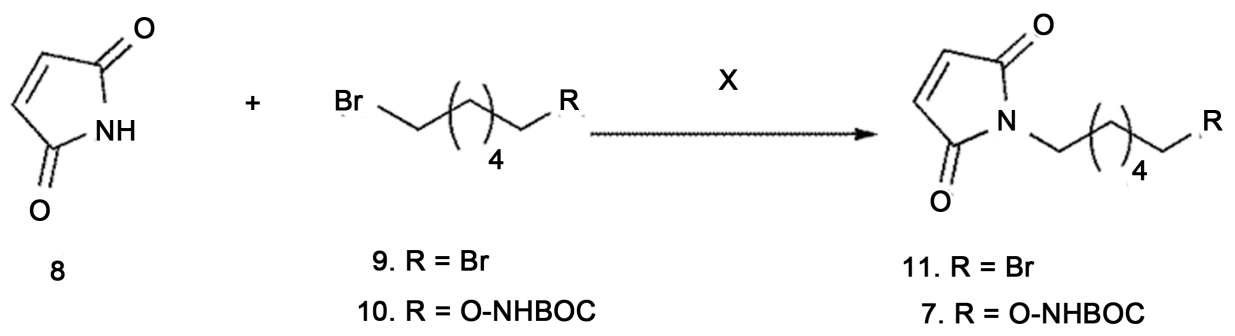

Scheme 2. N-alkylation of maleimde.
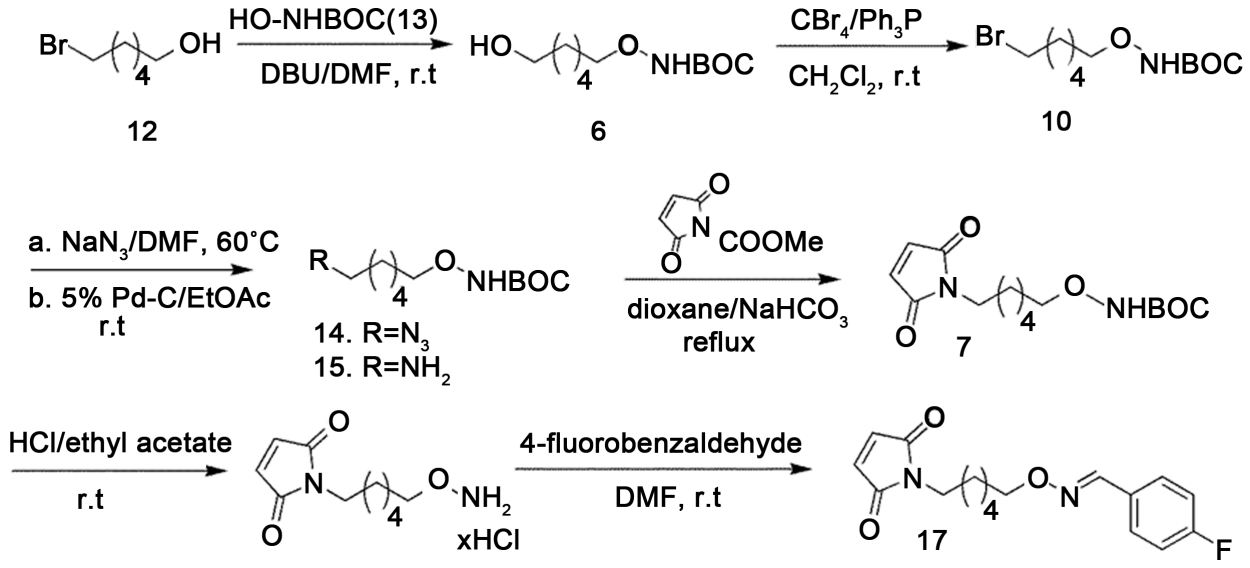

Scheme 3. Synthesis of precursor 16 and the standard 17.<smiles>C[N+](C)(C)c1ccc(C=O)cc1</smiles><smiles>CC(=O)CCC(C)C(=O)O</smiles>
microreactor, $2 \mathrm{~m} \times 100 \mu$<smiles>O=Cc1ccc(F)cc1</smiles>

19<smiles>CC(C)(CON=Cc1ccc([18F])cc1)CN1C(=O)C(=O)C(C(C)(C)CN2C(=O)C=CC2=O)C1=O</smiles>

Scheme 4. Synthesis of $\left[{ }^{18} \mathrm{~F}\right] \mathrm{FBAM}(1)$.

Table 1. Comparison of amount of precursor 18 used to obtain compound 1.

\begin{tabular}{cccc}
\hline Method & Precursor 18 & Solvent $(1 \mathrm{~mL})$ & Yield \\
\hline$[5]$ & $16.2 \mathrm{mg}$ & DMSO & $29 \%$ \\
{$[8]$} & $12.0 \mathrm{mg}$ & $\mathrm{DMF}$ & $28 \%$ \\
{$[6]$} & $10.0 \mathrm{mg}$ & $\mathrm{CH}_{3} \mathrm{CN}$ & $29 \%$ \\
Current & $5.0 \mathrm{mg}$ & $\mathrm{CH}_{3} \mathrm{CN}$ & $38 \%$ \\
\hline
\end{tabular}




\subsection{Materials and Methods}

All reagents and solvents were purchased from Acros or Aldrich and were used as received. Flash column chromatography was performed using silica gel (60 A, 230 - 400 mesh, Sorbent Technologies, USA) [13]. Analytical thin-layer chromatography (TLC) was performed using $250 \mu \mathrm{m}$ silica plates (Analtech, Inc., Newark, DE) with a visualization by UV $(254 \mathrm{~nm})$ or phosphomolebdic acid spray. ${ }^{1} \mathrm{H}$ and ${ }^{13} \mathrm{C}$-nuclear magnetic resonance spectra (NMR) were recorded at 300 or $125 \mathrm{MHz}$, respectively. Chemical shifts for ${ }^{1} \mathrm{H}$-NMR and ${ }^{13} \mathrm{C}-\mathrm{NMR}$ spectra were referenced to the residual protons of the deuterated solvents or to TMS. High resolution mass spectrometry was performed using a JEOL AccuTOF $^{\text {rm }}$ DART Mass Spectrometer. tert. Butyl $N$-[(6-hydroxyhexyl)oxy] carbamate was prepared following the literature procedure [14]. No-carrier-added $\left[{ }^{18} \mathrm{~F}\right] \mathrm{F}^{-}$, produced from recycled $\left[{ }^{18} \mathrm{O}\right]$ water, was obtained from PetNet (Knoxville, TN). Thin-layer chromatography visualization was performed with radiation detectors using a BioScan AR-2500 radio-TLC reader and Win Scan 1.3 software. Radio-TLC plates were developed using EtOAc/hexane (50/50). Analytical radio-HPLC analyses were performed on an Agilent 1200 series instrument employing a $254 \mathrm{~nm}$ UV detector and a Phenomenex Luna $\mathrm{C}_{18}$ column, $5 \mu, 4.6 \times 250 \mathrm{~mm}$, using $80 \%$ acetonitrile/20\% $0.1 \mathrm{~N}$ ammonium formate at a flow rate of $1 \mathrm{~mL} / \mathrm{min}$. F-18 labelling was performed in $100 \mu \mathrm{m}$ $\times 2 \mathrm{~m}$ reactor using Advion NanoTek Microfluidic Synthesis System controlled by NanoTek LF 1.4 Software.

tert-Butyl $N$-[(6-Hydroxyhexyloxy]carbamate (6)

To a magnetically stirred solution of $\mathrm{N}$-(tert-butyloxycabonyl)hydroxylamine, 13, (5.00 g, $37.6 \mathrm{mmol})$ and 6-bromohexane-1-ol, 12, (2.71 g, $1.50 \mathrm{mnol})$ was added DBU (11.4 g, $7.50 \mathrm{mmol}$ ) over a period of $5 \mathrm{~min}$. The mixture was allowed to stir for $24 \mathrm{~h}$ and then dissolved in $\mathrm{CH}_{2} \mathrm{Cl}_{2}(200 \mathrm{~mL})$, and the resulting solution was washed sequentially with $1 \mathrm{NHCl}(4 \times 25 \mathrm{~mL})$ and brine $(25 \mathrm{~mL})$. The aqueous portion was discorded and the $\mathrm{CH}_{2} \mathrm{Cl}_{2}$ was dried $\left(\mathrm{MgSO}_{4}\right)$, filtered, and concentrated. The resulting yellow oil was purified by silica gel flash chromatography (3:7, EtOAc:hexane) to provide tert-butyl $N$-[(6-hydroxyhexyloxy]-carbamate, 6, (8.48 g, 75\%). ${ }^{1} \mathrm{H} \mathrm{NMR} \mathrm{CDCl}_{3}(\delta) 1.39(\mathrm{~m}, 4 \mathrm{H})$, $1.47(\mathrm{~s}, 9 \mathrm{H}), 1.57-1.66(\mathrm{bm}, 4 \mathrm{H}), 3.62(\mathrm{t}, 2 \mathrm{H})$ and $3.84(\mathrm{t}, 2 \mathrm{H}) ;{ }^{13} \mathrm{C} \mathrm{NMR} \mathrm{CDCl}_{3}(\delta)$ 25.4, 25.6, 27.9, 28.4, 32.5, 62.7, 76.7, 81.5, 157.2; HRMS (ES) calculated for $(\mathrm{M}+\mathrm{Na})$ $\mathrm{C}_{11} \mathrm{H}_{23} \mathrm{NaNO}_{4}$ : 256.1525. Found: 256.1530 .

tert-Butyl $N$-[(6-Bromohexyloxy]carbamate (10)

Triphenylphosphine $(9.00 \mathrm{~g}, 34.0 \mathrm{mmol})$ and tert-butyl $\mathrm{N}$-[(6-hydroxyhexyloxy] carbamate, 6, (4.40 g, $17.2 \mathrm{mmol})$ were dissolved in anhydrous dichloromethane (30 $\mathrm{mL})$ under an argon atmosphere. Pyridine $(2.8 \mathrm{~mL}, 34.0 \mathrm{mmol})$ and carbon tetrabromide $(1.90 \mathrm{~mL}, 17.0 \mathrm{mmol})$ were added, and the reaction mixture stirred at room temperature for $24 \mathrm{~h}$. The mixture was poured into water, extracted with ether $(2 \times 50 \mathrm{~mL})$ and the combined organic extracts were dried (anhydrous $\mathrm{MgSO}_{4}$ ), filtered, and concentrated. The product was purified by silica gel flash chromatography (EtOAc/hexane, 2:7) to provide tert-butyl $N$-[(6-bromohexyloxy]carbamate, 10 , as a colorless oil (4.13 g, 82\%). ${ }^{1} \mathrm{H} \mathrm{NMR} \mathrm{CDCl}_{3}(\delta) 1.39\left(\mathrm{~m}, 4 \mathrm{H}, \mathrm{CH}_{2}\right), 1.47\left(\mathrm{~s}, 9 \mathrm{H}, \mathrm{CH}_{3}\right), 1.57-1.66(\mathrm{bm}, 4 \mathrm{H}$, 
$\left.\mathrm{CH}_{2}\right), 3.26\left(\mathrm{t}, 2 \mathrm{H}, \mathrm{CH}_{2} \mathrm{Br}\right)$ and $3.84\left(\mathrm{t}, 2 \mathrm{H}, \mathrm{OCH}_{2}\right) ;{ }^{13} \mathrm{C} \mathrm{NMR} \mathrm{CDCl}_{3}(\delta)$ 25.7, 25.9, 28.2, 28.4, 32.5, 32.9, 76.7, 81.5, 157.2; HRMS (ES) calculated for $(\mathrm{M}+\mathrm{Na}) \mathrm{C}_{11} \mathrm{H}_{22} \mathrm{NaNO}_{3} \mathrm{Br}$ : 318.0681. Found: 318.0685 .

tert-Butyl $N$-[(6-Aminohexyloxy]carbamate (15)

A mixture of tert-butyl $N$-[(6-bromohexyloxy]carbamate, $15(1.27 \mathrm{~g}, 4.30 \mathrm{mmol})$, sodium azide $(0.52 \mathrm{~g}, 8.0 \mathrm{mmol})$ and 18 -crown-6 $(0.53 \mathrm{~g}, 0.10 \mathrm{mmol})$ in anhydrous benzene $(10 \mathrm{~mL})$ was stirred overnight at $60^{\circ} \mathrm{C}$. Insoluble materials were filtered off and benzene was removed under vacuo to obtain the crude azide 14 (0.98 g) which was subjected to hydrogenation without purification. Azide $14(0.98 \mathrm{~g})$ was dissolved in dry EtOAc $(20 \mathrm{~mL})$ and hydrogenated at atmospheric pressure with 5\%-Pd/C using a hydrogen balloon. The catalyst was removed by filtration, the solvent evaporated and the product purified using silica gel flash chromatography (EtOAc/hexane, 2:7) to give tert-butyl $N$-[(6-aminohexyloxy-carbamate)], 15 (0.53 g; 54\%). ${ }^{1} \mathrm{H} \mathrm{NMR} \mathrm{CDCl}_{3}(\delta)$ 1.40-1.78 (m, 8H, $\left.\mathrm{CH}_{2}\right), 1.46\left(\mathrm{~s}, 9 \mathrm{H}, \mathrm{CH}_{3}\right), 2.62\left(\mathrm{t}, J=7.3 \mathrm{~Hz}, 2 \mathrm{H}, \mathrm{CH}_{2} \mathrm{NH} 2\right)$ and 3.78 $\left(\mathrm{t}, J=7.3 \mathrm{~Hz}, 2 \mathrm{H}, \mathrm{CH}_{2} \mathrm{O}\right.$ ); ${ }^{13} \mathrm{C} \mathrm{NMR} \mathrm{CDCl}_{3}(\delta) 25.3,25.8,27.9,28.4,32.5,41.9,76.7$, 81.5, 157.2; HRMS (ES) calculated for $(\mathrm{M}+\mathrm{Na}) \mathrm{C}_{11} \mathrm{H}_{24} \mathrm{NaN}_{2} \mathrm{O}_{3}$ : 255.1735. Found: 255.1738 .

tert-Butyl $N$-\{[6-(1-Maleimidyl)hexyl]oxy\}carbamate (7).

To a solution of tert-butyl $N$-[(6-aminohexyloxy]carbamate, $15,(1.1 \mathrm{~g}, 5.0 \mathrm{mmol})$ in THF $(100 \mathrm{~mL})$ was added $N$-methoxycarbonylmaleimide $(2.43 \mathrm{~g}, 25.0 \mathrm{mmol})$. The mixture was stirred overnight at reflux. A precipitate was formed. After filtration, the filtrate was concentrated to dryness, and the residue purified by flash column chromatography using silica gel and EtOAc/hexane (2:7) to give pure tert-butyl $N$-\{[6-(1-maleimidyl)hexyl]oxy\}carbamate, 7, (1.21 g, 78\%). ${ }^{1} \mathrm{H} \mathrm{NMR} \mathrm{CDCl}_{3}(\delta) 1.47\left(\mathrm{~s}, 9 \mathrm{H}, \mathrm{CH}_{3}\right)$, $1.21-1.61\left(\mathrm{bm}, 8 \mathrm{H}, \mathrm{CH}_{2}\right), 3.49\left(\mathrm{t}, J=7.4 \mathrm{~Hz}, 2 \mathrm{H}, \mathrm{NCH}_{2}\right), 3.84(\mathrm{t}, J=6.9 \mathrm{~Hz}, 2 \mathrm{H}$, $\mathrm{OCH}_{2}$ ), 6.64 (s, $2 \mathrm{H}$, maleimide) and $7.10(\mathrm{br} \mathrm{s}, 1 \mathrm{H}, \mathrm{NH}) .{ }^{13} \mathrm{C} \mathrm{NMR} \mathrm{CDCl}_{3}(\delta) 25.4,25.6$, 27.9, 28.4, 32.5, 62.7, 76.7, 81.5, 157.2; HRMS (ES) calculated for $(\mathrm{M}+\mathrm{Na})$ $\mathrm{C}_{15} \mathrm{H}_{24} \mathrm{NaN}_{2} \mathrm{O}_{5}: 335.3513$. Found: 335.3518

$N$-(6-Aminoxyhexyl)maleimide $\mathrm{HCl}(\mathbf{1 6})$.

A solution of tert-butyl $N$-\{[6-(1-maleimidyl)hexyl]oxy\}carbamate, 7, (1.20 g, 3.84 $\mathrm{mmol})$ in $3 \mathrm{~N} \mathrm{HCl} / \mathrm{EtOAc}(1: 1,40 \mathrm{~mL})$ was stirred for $30 \mathrm{~min}$ at room temperature. The solvent was removed under reduced pressure, and the residue dissolved in methanol $(10 \mathrm{~mL})$. Diethyl ether $(100 \mathrm{~mL})$ was added and the white suspension was filtered to obtain $\mathrm{N}$-(6-aminoxyhexyl)maleimide $\mathrm{HCl}, 16,(0.90 \mathrm{~g}, 95 \%), \mathrm{mp}=132^{\circ} \mathrm{C}-133^{\circ} \mathrm{C}$ (lit. $\left.135^{\circ} \mathrm{C}-137^{\circ} \mathrm{C}\right) .{ }^{1} \mathrm{H}$ NMR DMSO $(\delta) 1.21-1.52\left(\mathrm{bm}, 4 \mathrm{H}, \mathrm{CH}_{2}\right), 1.61-1.74(\mathrm{bm}, 4 \mathrm{H}$, $\left.\mathrm{CH}_{2}\right), 3.48\left(\mathrm{t}, J=7.4 \mathrm{~Hz}, 2 \mathrm{H}, \mathrm{NCH}_{2}\right), 3.88\left(\mathrm{t}, J=6.9 \mathrm{~Hz}, 2 \mathrm{H}, \mathrm{OCH}_{2}\right), 6.84(\mathrm{~s}, 2 \mathrm{H}$, malei-

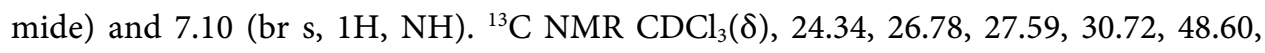
$49.58,134.30$ and 170.8

$\mathrm{N}$-[6-(4-Fluorobenzylidine)aminooxyhexyl]maleimide (17)

A mixture of 4 -fluorobenzaldehyde $(0.037 \mathrm{~g}, 0.40 \mathrm{mmol})$ and $\mathrm{N}$-(6-aminoxyhexyl) maleimide $\mathrm{HCl}, 8,(0.05 \mathrm{~g}, 0.20 \mathrm{mmol})$ in dimethyl formamide $(5 \mathrm{~mL})$ was stirred for 30 $\mathrm{min}$ at room temperature. The reaction mixture was diluted with water $(30 \mathrm{~mL})$ and 
extracted with diethyl ether $(2 \times 25 \mathrm{~mL})$. The ether extracts were washed with brine (10 $\mathrm{mL}$ ) and dried (anhydrous $\mathrm{MgSO}_{4}$ ). The solvent was evaporated under reduced pressure and the crude product was purified using silica gel flash chromatography (EtAcO/hexanes, 7:3) to give $N$-[6-(4-fluorobenzylidine)aminooxyhexyl]maleimide, 17, (0.06 g, 94\%) as a white solid. ${ }^{1} \mathrm{H} \mathrm{NMR} \mathrm{CDCl}_{3}(\delta) 1.21-1.70\left(\mathrm{bm}, 8 \mathrm{H}, \mathrm{CH}_{2}\right), 3.48(\mathrm{t}, J=$ $7.4 \mathrm{~Hz}, 2 \mathrm{H}, \mathrm{NCH}_{2}$, ), $4.10\left(\mathrm{t}, J=6.9 \mathrm{~Hz}, 2 \mathrm{H}, \mathrm{OCH}_{2}\right.$ ), 6.68 (s, 2H, maleimide), 7.01 (m,

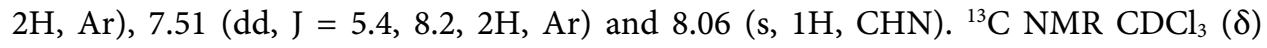
26.41, 27.05, 30.72, 49.56, 59.38, 115.73, 130.06, 134.31, 134.75, 163.35 and 170.82; HRMS (ES) calculated for $(\mathrm{M}+\mathrm{Na}) \mathrm{C}_{15} \mathrm{H}_{24} \mathrm{NaN}_{2} \mathrm{O}_{3}: 322.7864$. Found: 322.7868

$N$ - $\left\{6-\left(4-\left[{ }^{18} \mathrm{~F}\right]\right.\right.$ Fluorobenzylidine)aminooxyhexyl $\}$ maleimide (1)

The details of operation of the NanoTek Microfluidic System have been described previously (Pike 2009, 2010). Cyclotron-produced, no-carrier-added $\left[{ }^{18} \mathrm{~F}\right]$ fluoride ion $(100 \mathrm{mCi})$ in $\left[{ }^{18} \mathrm{O}\right]$ water $(225-350 \mu \mathrm{L})$ was first adsorbed onto an anion exchange resin ORTG cartridge within the concentrator module of a NanoTek apparatus (Advion Biosciences), and then released with a solution of $\mathrm{K}_{2} \mathrm{CO}_{3}(1.8 \mathrm{mg})$ plus $\mathrm{K}_{2.2 .2}(12.0 \mathrm{mg})$ in $\mathrm{MeCN} / \mathrm{H}_{2} \mathrm{O}(9.5: 0.5 \mathrm{v} / \mathrm{v} ; 400 \mu \mathrm{L})$ into a $5 \mathrm{~mL} \mathrm{~V}$-vial. The solution was dried by three cycles of azeotropic evaporation with $\mathrm{MeCN}(0.45 \mathrm{~mL})$ at $100^{\circ} \mathrm{C}$. The dry ${ }^{18} \mathrm{~F}^{-}-\mathrm{K}_{2.2 .2}-\mathrm{K}^{+}$ complex $(70 \mathrm{mCi})$ was dissolved in $\mathrm{MeCN}(0.5 \mathrm{~mL})$. The isotope solution was then loaded into the loop of the reactor module $(431 \mu \mathrm{L})$, and $4-N, N, N$-trimethyammoniumbenzaldehyde, $18,(2.5 \mathrm{mg}$ in $0.5 \mathrm{~mL})$ solution was loaded into the other loop on the reagent module $(431 \mu \mathrm{L})$. These solutions were concurrently infused into a $2 \mathrm{~m}$ long micro reactor coil $(100 \mu \mathrm{m})$ at a combined flow rate of $200 \mu \mathrm{L} / \mathrm{min}$. The radiofluorinated product exiting the micro reactor was collected in a vial, in the concentrator module, containing maleimide precursor $16(8 \mathrm{mg})$ dissolved in a mixture of methanol and $1.0 \mathrm{~N} \mathrm{HCl}(1 \mathrm{~mL}, 50 / 50)$ and the resulting mixture was heated at $75^{\circ} \mathrm{C}$ for $10 \mathrm{~min}$. After cooling, the mixture was diluted with water $(15 \mathrm{~mL})$ and passed through $\mathrm{C}_{18}$ SepPak cartridge to eliminate water soluble precursor and any unreacted isotope. The product was eluted with acetonitrile $(3 \mathrm{~mL})$. The pure product was isolated by semipreparative HPLC column (Phenomenex Luna reverse phase column, $250 \times 10 \mathrm{~mm}, 10$ $\mu$ ), using gradient elution (A: $\mathrm{CH}_{3} \mathrm{CN}$, B: $0.1 \mathrm{M}$ ammonium formate, $0.5 \mathrm{~min} 40 \% \mathrm{~A}$ and $60 \% \mathrm{~B} ; 5-15 \mathrm{~min} 40 \% \mathrm{~A}-70 \% \mathrm{~A}$ and $15-30 \mathrm{~min} 70 \% \mathrm{~A}$, flow rate $4 \mathrm{~mL} / \mathrm{min}$ ). A fraction (16 - $18 \mathrm{~min})$ was collected, diluted with water $(10 \mathrm{~mL})$, and passed through a $\mathrm{C}_{18}$ Sep-Pak cartridge to trap the desired product. The cartridge was then washed with diethyl ether $(2 \mathrm{~mL})$ and the solvent evaporated under a stream of dry $\mathrm{N}_{2}$ to afford 29 $\mathrm{mCi}$ (38\% decay corrected) of $\left[{ }^{18} \mathrm{~F}\right] \mathrm{FBAM}$. The identity of the product was confirmed using analytical HPLC by co-injection with a reference standard, $17, \mathrm{R}_{\mathrm{t}}=6.4 \mathrm{~min}$.

\section{Conclusion}

$\left[{ }^{18} \mathrm{~F}\right] \mathrm{FBAM}$ was successfully synthesized by continuous flow chemistry using an Advion NanoTek Microfludic Synthesis System in high radiochemical yield $(38 \% \pm 4 \%, \mathrm{n}=4$; previously reported $29 \% \pm 4 \%$ ) and radiochemcial purity of $\geq 98 \%$. The requisite key precursor $\mathrm{N}$-(6-amino-oxyhexyl)maleimide $\mathrm{HCl}, 16$, was prepared by a different method 
then that previously reported. Smaller quantities of expensive precursors were used for the synthesis under microfluidic conditions. The overall time for the synthesis was 55 min and the specific activity was determined to be $430 \mathrm{mCi} / \mu \mathrm{mol}$.

\section{References}

[1] Wilbur, D.S. (1992) Radiohalogenation of Proteins-An Overview of Radionuclides, Labeling Methods, and Reagents for Conjugate Labeling. Bioconjugate Chemistry, 3, 433-470. http://dx.doi.org/10.1021/bc00018a001

[2] Sosabowski, J., Melendez-Alafort, L. and Mather, S. (2003) Radiolabelling of Peptides for Diagnosis and Therapy of Non-Oncological Diseases. The Journal of Nuclear Medicine, 47, 223-237.

[3] Giblin, M.F., Veerrendra, B. and Smith, C.J. (2005) Radiometallation of Receptorspecific Peptides for Diagnosis and Treatment of Human Cancer. In Vivo, 19, 9-29.

[4] Rennen, H.J., Corstens, F.H., Oyen, W.J. and Boerman, O.C. (2001) New Concepts in Infection/Inflammation Imaging. The Journal of Nuclear Medicine, 45, 167-173.

[5] Brendt, M., Pietzsch, J. and Wuest, F. (2007) Labeling of Low-Density Lipoproteins Using the ${ }^{18} \mathrm{~F}$-Labeled Thiol-Reactive Reagent $N$-[6-(4-[18F]fluorobenzylidene)aminooxyhexyl] maleimide. Nuclear Medicine and Biology, 34, 5-15. http://dx.doi.org/10.1016/j.nucmedbio.2006.09.009

[6] Kniess, T., Kuchar, M. and Pietzsch, J. (2011) Automated Radiosynthesis of the ThiolReactive Labeling Agent N-[6(4-[F-18]fluorobenzylidene)aminooxyhexyl]maleimide ([18-F)]FBAM). Applied Radiation and Isotopes, 69, 1226-1230. http://dx.doi.org/10.1016/j.apradiso.2011.03.043

[7] Wuest, F., Kohler, L., Berndt, M. and Pietzsch, J. (2009) Systematic Comparison of Two Novel, Thiol Reactive Prosthetic Groups for F-18 Labeling of Peptides and Proteins with the Acylation Agentsuccinimidyl-4-[F-18]fluorobenzoate ([F-18]SFB). Amino Acids, 36, 283-295. http://dx.doi.org/10.1007/s00726-008-0065-2

[8] Toyokini, T., Walsh, J.C., Domingez, A., Phelps, M.E., Barrio, J.R., Gambhir, S.S. and Satyamurty, N. (2003) Synthesis of a New Heterobifunctional Linker, $N$-[4-(aminooxy) butyl]maleimide, for Facile Access to a Thiol-Reactive 18F-Labeling Agent. Bioconjugate Chemistry, 14, 1253-1259. http://dx.doi.org/10.1021/bc034107y

[9] Moore, T., Akula, M. and Kabalka, G.W. (2016) Fluorine-18 Radiochemistry a Novel Thiol Reactive Prosthetic Group [18 F]FPyAM. Natural Science, 8, 1-7.

http://dx.doi.org/10.4236/ns.2016.81001

[10] Bruin, B., Kuhnast, Bhinnen, F., Yaouanc, Q., Lamessou, M., Johannes, L., Samson, L., Boisgard, R., Tavitian, B. and Dolle, F. (2005) 1-[3-(2-[ $\left[{ }^{18} \mathrm{~F}\right]$ Fluoropyridin-3-yloxy)propyl] pyrrole-2,5-dione: Design, Synthesis, and Radiosynthesis of a New $\left[{ }^{18} \mathrm{~F}\right]$ fluoropyridine-Based Maleimide Reagent for the Labeling of Peptides and Proteins. Bioconjugate Chemistry, 16, 406-420.

[11] Seebach, D., Pichota, A., Beck, A., Pinkerton, A.B., Litz, T., Karjalainen, J. and Gramlich, V. (1999) Preparation of TADDOL Derivatives for New Applications. Organic Letters, 1, 5558. http://dx.doi.org/10.1021/ol990060d

[12] Nakajima, Y., Oda, J. and Inouye, Y. (1978) Stereochemical Studies on Azidation of b-Bromohydrins under Phese Transfer Condition. Tetrahedron Letters, 34, 3107-3110. http://dx.doi.org/10.1016/S0040-4039(01)94955-X

[13] Still, W.C., Kahn, M. and Mitra, A. (1978) Rapid Chromatographic Technique for Preparative Separations with Moderate Resolution. Journal of Organic Chemistry, 43, 2923-2925. 
http://dx.doi.org/10.1021/jo00408a041

[14] Jones, D.S., Ammaker, J.R. and Tedder, M.E. (2001) A Convenient Synthesis of N-(tertbutyloxycarbonyl)aminooxyethers. Tetrahedron Letters, 41, 1531-1533.

http://dx.doi.org/10.1016/S0040-4039(99)02331-X

Submit or recommend next manuscript to SCIRP and we will provide best service for you:

Accepting pre-submission inquiries through Email, Facebook, LinkedIn, Twitter, etc.

A wide selection of journals (inclusive of 9 subjects, more than 200 journals)

Providing 24-hour high-quality service

User-friendly online submission system

Fair and swift peer-review system

Efficient typesetting and proofreading procedure

Display of the result of downloads and visits, as well as the number of cited articles

Maximum dissemination of your research work

Submit your manuscript at: http://papersubmission.scirp.org/

Or contact ijoc@scirp.org 